\title{
EMBODIMENT CONCEPT OF GOOD GOVERNANCE AS PRINCIPLES IN PUBLIC PROCUREMENT
}

\author{
Richo Andi Wibowo \\ Faculty of Law, Universitas Gadjah Mada \\ Researcher in Institute of Constitutional and Administrative Law, Utrecht University \\ richo.wibowo@ugm.ac.id \\ r.a.wibowo@uu.nl
}

\begin{abstract}
Abstraksi
Banyak pihak meyakini good governance adalah meta-konsep yang dapat diimplementasikan pada seluruh level. Tulisan ini berupaya membuktikan hal tersebut dengan meninjau bagaimanakah pembadanan good governance dari "konsep" menjadi "asas", khususnya di sistem pengadaan barang/jasa. Untuk itu, tulisan ini akan mengelaborasi konsep dan sejarah good governance, kemudian menunjukkan bagaimana konsep tersebut terserap dan bekerja sebagai asas. Tulisan ini akhirnya berkesimpulan bahwa good governance adalah konsep yang "avant la lettre", yang mana konsep tersebut telah terbadankan secara utuh sebagai asas good governance, namun terbadankan dengan beberapa modifikasi sebagai asas di sistem pengadaan barang dan jasa.
\end{abstract}

Kata kunci: Konsep, Asas, Sejarah, Good Governance, Pengadaan Barang/Jasa

\section{INTRODUCTION}

This introduction section, is aimed to examine the concept and history of good governance. It is used to sense the development of idea, the spirits, and the sbjectives of the good governance. The senses are useful to examine how the concept of good governance embodied as public procurement principle. At the end of this section, one main research question and three sub research questions will be addressed.

\section{History of Good Governance Concept}

Tracing back from the history, the notion of good governance was firstly distinguished by World Bank (WB) in 1989. Beforehand, the Bank used only term 'governance' (without 'good') to describe the need for institutional reform and better and more efficient public sector in SubSaharan countries (Maldonando, 2010). Later on, the word "good" was attached together with . the word "governance" and used it more frequently (Addink, 2012). This good governance terminology, then also developed by International Monetary Fund (IMF), United Nations (UN) and other international organizations. IMF uses good governance concept as criterion of assistance (Botchway, 2001) whereas UNDP uses the concept as guidelines to be adopted by the state as the way to solve poverty, inequity and insecurity (www.mirror.undp.org, last accessed 15/11/2012).

Hence, at the first glance, it can already be seen that those three international organizations use the same phrase of "good governance" but they do not always refer the same meanings. According a further research, financial organizations define good governance mainly to address economic institutions and public sector mánagement, including transparency 
and accountability, regulatory reform and public sector skills and leadership on the macro economic context (Gisselquist, 19/11/2012), whereas other organizations, like United Nations are more highlighting democratic governance and human rights $(I b i d)$. Respecting the ideas above, this paper formulates its own views: good governance is a concept contained good value to guideline the state to achieve better performance to serve its main duty: servicing its citizen.

As those international organizations started promoting the same terminology in almost at the same period; then people regards that good governance were firstly stemmed and developed by those organizations. Indeed, that opinion might be incorrect, as the discussion about guidelining the state to achieve better performance has been discussed since very long time ago.

In the early twentieth century for instance, Max Weber has outlined the functions of bureaucracy that can be seen as the base of (good) "governance" concept (Botchway, 2001). Weber identified three grounds of governance: traditional, charismatic, and rational (Weber, 1978). The first ground rooted on the blind faith in tradition and the inviolability of the rulers whereas the second ones based on the acknowiedgement of unique qualities of the leader (Weber, $I b i d$ ). Weber regarded that the third model (rational ground) is the best format as it has rooted on two substance rational legal system and bureaucracy (Ibid).

Rational legal system creates a system that is driven by legal code which should be obeyed by the society. In order to do so, the regulation should be logic, not arbitrary and accepted by the society (Botchway, 2001). Therefore, it is coherence with the concept of rule of law. In addition to that, the objective of "accepted by the society" indicates that the formulation of the policy/regulation should be carried on openly. It is to assure that public can be participated in the policy-making. Thus, these ideas guide the state to conduct openness and participation, the two elements of good governance.

Weber's normative form of governance also requires bureaucracy. This system designed to avoid the possibility of confusing the citizen. When the citizen makes a contact to the government, the system should ensure the citizen to calculate the output of the contact by examining/understanding regulations. Hence, Weber's concept of bureaucracy related to principle of legal certainty and legitimate expectation, the two sub principles in principles of properness; one of the elements of good governance.

Based on the elaboration above, the ideas of good governance have been discussed before it was distinguished by the international organizations in 1990s. On the further elaborations, this paper also show that element of good governance had also been discussed since 16 century.

\section{Concept of Public Procurement and Its History}

In the public finance literature, government is involved in four major economic activities (Thai, 2001): (a) providing legal framework for all economic activities; (b) redistributing income through taxation and spending; (c) providing public goods and services freely available to the public such as national defense, public safety, education, and infrastructure (bridges and roads); and (d) purchasing goods, services and capital assets. Providing and purchasing public goods and/or services are done by the mechanism which so called as public procurement. In some literature, this terminology also called as government procurement or government contracts.

There is no clear information about when procurement firstly held. One source believed that procurement activity has been conducted since 3000 BC in Egypt, to supply of pyramid 
materials, workers and papyrus rolls (Brummer, last visited: 28/10/2012). Sliglitly different with that, C.K. Coe believed that the earliest procurement order dates from between 2400 and 2800 B.C in Syria, to order " 50 jars of fragrant smooth oil for 600 small weights in grain" (Thai, 2010).

The modern development, later on, can be seen in 1810. Page noted that Oklahoma, a local government in the United States, was the first state government to create a board to procure centrally for all state departments and agencies (Thai, lbid). This development then followed by other countries (lbid).

According to Thai, the bad practices in conducting procurement frequent to happen, and it still continue even though the government efforts in procurement reform (2010). Indeed, Thai did not mention which problem specifically that he talked about; however, his opinion is seemingly true. According to Kauffman, public procurement is the most vulnerable government activities in 117 countries (OECD, 2007). Indeed, it is estimated that from $10 \%$ to $50 \%$ of the contract value damage in this sector (Kostyo, 2006).

\section{Linkage Between Good Governance and Public Procurement}

Recognizing that good governance have positive values, and realizing the problems laid in public procurement system, then this paper hypothyzed that the concept of good governance can be used to enhance the public procurement system. Indeed, this paper will not try proof this hypothesis. It will more on elaborating to what extend the "concept" of guod governance can be or have been embodied as the "principle" of (good) public procurement.

Indeed, it is sometimes fuzzy to differentiate between concept and principle. One argued that principle is broader than concept (concept is a sub part of principle) (Botchway, 2001) whereas another regards that principle is legal character, something that links with other principle of law exist (Addink, 2012); thus principle can be interpreted a sub part of concept. However, this paper regards that "concept" as the general-broad idea which later on can be more specified in legal context as "principle".

\section{Research questions and the limitation of this paper}

Actually, every organization promotes different elements of good governance. WB promotes four elements of good governance (As it has been cited by IFAD, 1999). IMF, indeed, does not have clear elements of (good) governance to be promoted. However, IMF indicates share the same perception with World Bank (www.imf.org, last visited 20/11/2012) while UNDP promotes 15 elements (www.mirror.undp.org, last visited 20/11/2012). In order to be focus, this research will limit the elaboration on three elements of good governance, namely equity, transparency and accountability.

Equity is chosen as its has a sub element called "equality". This sub element play significant role in guiding public procurement activity. "Accountability" is chosen as the golden concepts of modern (good) governance (Bovens, Schilleemans, and t' Hart, 2008). Another expert, G.Hodge called accountability as the lifeblood in guarding the public interest (Busuoic, 2010). Therefore, it is highly important to include this element in this paper. Lastly, "transparency" is chosen as it is impossible to reach accountability without transparency. In other words, transparency is the preliminary condition that should be existed in order to achieve accountability. Hence, transparency is highly important to be mention in this paper.

In general, this paper is aimed to address one main research question: how is concept of good governance embodied in the principles of public procurement? However, in order to be coherence with the focus above, this paper also has three sub questions: (i) how is concept equity embodied in principle of equality in public procurement?; (ii) how is concept 
transparency embodied in principle of transparency in public procurement?; and, (iii) how is concept accountability embodied in principle of accountability in public procurement?

\section{ELABORATION}

\section{Equity, Equality, and Public Procurement}

According to literature, the concept of equity has firstly developed in moral context by Aristotle. He has differentiated between equity and equality. Aristotle regards that equality means things that are alike should be treated alike while things that are unalike should be treated unalike in proportion to their unalikeness (Bernard, 1998).

It is believed that continue to discuss, but many people regards that the concept became mushrooming in 18 century when the enlightenment begin in Europe. It started with the idea of Locke, Paine and Rousseau that each person matters equally (E.Meehan in Bernard, 1998). Then, this idea is embodied in the French Declaration of the Rights of Men (www.diplomatie. gouv.fr, last visited 16/11/2012) and US-Declaration of Independence (www.archives.gov, last visited 16/11/2012).

From the description of the history above, indeed, Aristotle has mentioned both the concept of equity and the concept of equality. However, the development that happened in Europe and the US indicated that -at that time- people are discussed more about equality, and not equity. Seemingly, it contributes to the confusing for some people; some argued that these terms referred to the same meaning (http://legal-dictionary.thefreedictionary.com, last visited 14/11/2012) while Victor Hugo look it as a two things that related but have different meaning (Karsam, 16/11/2012).

According to Cambridge dictionary, 'equity' is a situation when everyone is treated fairly and equally (e-Cambridge Dictionary, 2003) whereas equality is the right of different groups of people to have a similar social position and receive the same treatment. Better explanation about the difference of those two concepts are given by American Library Association as follows: 'equality' is giving everyone in the same access, the same opportunity, etc while 'equity' regards that there are unequal situation happen in the society, so giving merely equal access and opportunity is less sufficient, they should obtain fairness and (positive) affirmation (Nancy Kranich, 2005).

From the elaboration above, this paper views that equity is a broad concept. The objective is that to achieve fairness and justice. These two achievements can be reached by two ways: conducting equality or implementing positive affirmation.

In public procurement system, generally, principle of equity is simply manifested as principle of equality. Regulation usually designs the procurement system to make equal opportunities and equal treatments for providers (Arrowsmith, 2010). Equal opportunities are simply meant as not blocking the opportunity of the potential bidders to participate in the bidding process whereas equal treatments are interpreted as avoiding the different treatment to every bidder which has submitted the bidding proposals.

These two principles should be conducted in order to make 'level playing field' among the bidders. By doing so, it is believed that the government will obtain the various-good offers from the bidders; hence, it can allow the procurement committee to examine and then to select the best offer among those. 
"Equal opportunities" can be carried out by conducting transparency in which the elaboration will be mentioned in the next chapter. In essence, equal opportunities require the tender committee to announce "the request for tender" widely to public and allow them to participate in the tender process. However, for some reasons, there are possibilities to not conduct this principle as two paragraphs elaborated below.

A country may set a regulation contained positive affirmation to small enterprises. In Indonesia for instance, these enterprises are encouraged to participate in small value tenders within nominal below a hundred million IDR (Art. 39 (1) (d), President Regulation No 54/2010). A big company can not participate in this bidder. It is created so in order to avoid "David vs Goliath" competition. This illustration can be seen as infringement of equality principle; however, it can also be seen promotion of equity principle.

Beside that, procurement system may also have close procedure for conducting tenders. Under close (restricted) procedure, only a limited number of invited firms are permitted to submit tenders. The tender committee sent request to participate to some particular firm(s) which seen eligible to carry the project offered. Restricted tenders can happen in order to accelerate or simplify the procurement process due to: (i) urgency reasons (Arrowsmith, Ibid; see also for instance, Art. 38 (1) President Regulation No 54/2010); and/or (ii) belief that the project can only be carried out by particular firms (Art 1 (24) President Regulation No 54/2010).

Beside that, equal opportunities may be interpreted differently in every country. In Indonesia, this principle is meant as giving the same opportunity to all national firms to participate in tender process. Indonesia's regulation prioritizes the national firms rather than firms from outside Indonesia (Art. 101 President Regulation No 54/2010). In EU legal regimes, equal opportunities are meant as giving the same opportunities to any firms in EU member countries to participate in government tender.

The elaboration for "equal treatment" will not as complicated as "equal opportunities" above. Indeed, equal treatment, usually, has been embodied in various articles in procurement regulation. It is to assure that all stakeholders involved in the tender process are not allowed to conduct actions that can infringe the objective of creating 'level playing field'. In Indonesia and in EU countries, the violations of this principle can happen due to corruption, but particularly in EU the infringements of this principle can also happen as discrimination on grounds of nationality (Arrowsmith, Ibid).

In summary, the elaboration above showed that the concept of equity has been developed since 18 century. This concept, then, extracted as principle of equity in good governance. This principle is meant as principle of equality in public procurement's legal regime. Principle of equality is divided into two sub principles: equality on participation and equality on treatment. In general, these two sub principles are respected and implemented; however, in particular condition these two sub principles are set to not worked out to protect the objective of the procurement.

\section{Principle of Public Procurement Transparency in Good Governance}

The history of transparency can be traced back in Sweden. This Northern European country has made law that regulates the public access to government documents since 1766 (G.H. Addink, Ibid). It indicated how develop/modern the Sweden people at that time. It can be said so as before the regulation was issued, public discussions about the urgency of the public access had happened. 
Several years after the development above, the history of France was also found contributed to the development of the transparency concept; even though less developed than in Sweden. In 1774, Louis XVI was coroneted as the King of France (www.biography.com, last visited 20/11/2012). Unlike Louis XV, his father, Louis XVI tried to reform the France kingdom to raise the legitimacy.

One of his relevant statements was: "I must always consult in public opinions, it is never wrong" (Melten, 2004). In addition to that, one of his important actions related to transparency is that he tried to mobilize public opinion to support his royal decisions. He was doing so by printed propaganda and published detail information of particular policies (i.e. war policies) (Melten, Ibid). In this paper point of view, the king actions above can be seen as the early development of transparency implementation.

In recent era, the concept of transparency has been developed by various organizations. According to Transparency International, the concept of transparency ensures that public officials, civil servants, managers, board members and businesspersons act visibly and understandably, and report on their activities in order to make sure that the public can hold them to account (www.transparency.org, last visited, 09/10/2012). Beside that, UNDP regards that transparency is built on the (needs of) free flow of information (mirror.undp.org, last visited 20/11/2012). It is important to assure that processes, institutions and information are directly accessible, understandable, and watchable to those concerned (lbid). Recognizing those ideas above, this paper regards that transparency is a concept that can eliminate the potency of harmful action conducted by actor(s) by allowing and/or providing information to the stakeholders.

The concept of transparency has been embodied deeply in legal system. As two instances, transparency can be seen in the article 19 of Universal Declaration of Human Rights which said: "everyone has the right to freedom of opinion and expression..." (http://www. un.org, last visited 28/12/2012). It can be seen also in the article of 19 International Covenant on Civil and Political Rights (ICCPR) which said everyone has the right "...to seek, receive and impart information and ideas through any media..." (http://www2.ohchr.org/english/law/ ccpr.htm\#art19, last visited 28/12/2012). Beside these, the concept of transparency is also institutionalized in the constitutions and/or acts in national context (http://www.undppc.org.fj, last visited 20/11/2012). Therefore, as transparency has been embodied on the regulation, the term of "principle" will be used.

According to Birkinshaw (2005), the elements of legal transparency are: clarity of procedures, clear drafting, publication and notification of decision, duty to give reasons predictability of public authorities, and consistency in the interpretation and application of the law. By performing this, it is hoped that individual citizens can acquire the information, then examine the correctness of the government actions (Addink, 2012).

In the legal context, the term "transparency" may be referred to three meanings: access to information, transparency and openness (Birkinshaw, 2005). The first subject is meant as access by individuals as a presumptive right to information held by public authorities (Addink, 2012). The second subject is referred to access of information as which subject to public scrutiny (lbid). It is conducted by keeping observable records of official decisions including providing explanation for the reason of decisions. The third subject is concentrated more on process that allowing the citizen to see the operations and activities of the government (Ibid). Hence, the implementation of 'openness' can be seen as the step forward of 'transparency'.

There were pros and contras about how far the principle of transparency should work. The pro's group regard that it is important to make all the government information accessible 
(to make the government as open as possible) while the contra's group see that providing all the government information can undermine public and national security (Birknishaw, 2005); thus transparency should be limited. The pro's group challenges this contra-opinion by citing the court decision, "secrecy is a way to silence... the voice of critic and hide the knowledge of the truth" (lbid).

Giving the fact of those debate above; this paper belief that providing all information available publicly -indeed- may undermine the security interest, but keeping it secrecy will also potentially make the government conduct unaccountable action; so it can undermine the public interest. Thus, it is important to make gradation of the implementation in principle of transparency. The gradation can be carried out by issuing regulation explained the categorization which information that should remain confidential. The information under this list may not be published to public. This categorization should have rational and clear arguments. However, the regulation should also explain the limitation time of the documents regarded as secrecy. Later on, it should be opened to assure public can examine the correctness of the action conducted by the government (Addink, 2012). In order to do so, the regulation should also rule that the documents will not be destroyed.

The elaboration will continue the elaboration above with emphasizing principle of transparency in public procurement. This sub parts will argue that principle of transparency has been embodied in public procurement, but then there is a particular time to exclude the implementation of this principle. It happens to assure that market can work optimally.

There are many problems in public procurement system, some of those happen as the nature of asymmetric information. The unequal information, usually, are set by the tender committee. These follow are some instances of its modus operandi (Hardjowiyono and Muhammad, 2004): first, committee announces public procurement in less popular newspaper, consequently, many vendors will not aware with the offer except for those who have collusion with the committee; second, committee announces incomplete information in advertisement. As a result, the interested vendors do not get clear information except those who make connection with the committee; third, committee requires the submission of tender proposal in particular place or time which can be seen as irrational to be achieved; hence, only vendors which affiliated with the committee that can fulfill the proposal.

Those three modus operandi certainly infringe principle of equality. However, the first two modus do also infringe principle of transparency. It can be so as, principle of transparency in public procurement mandates that "the degree of advertising sufficient to enable the services market to be opened up to competition and the impartiality of the procurement process to be reviewed" (Arrowsmith, 2010).

Paragraph above showed how principle of transparency sharpened in the context of public procurement. Indeed, the sharphening of this principle can also be seen on the regulation. UNCITRAL Model Law on Procurement 2011 gives guidance; an instance of this is rules concerning the manner, place and deadline for presenting applications to pre-qualify or applications for pre-selection or for presenting submissions (www.uncitral.org, last accessed 21/11/2012).

Beside judgement and regulations, the experts' comments can also be used to sharpen principle of transparancy in order to be worked optimally in procurement system. Arrowsmith, Lineralli and Wallace for instance (in Arrowsmith, 2010), have breaking down principle of transparency into four sub principles as follows: (i) publishing (clearly) contract opportunities; (ii) providing the procurement laws and policies in each procedure; (iii) explaining rule based decision making to limit discretion; (iv) creating system that allowing verification between the fact and that the rules and policies mentioned above. 
Another thing that also related to principle of transparency in public procurement is that there is a time to exclude the implementation of transparency. It happens between the time for submitting tender proposal and the time of evaluating the proposal by the tender committee.

The exclusion needed to assure market can work optimally. If a bidder can examine the content of other bidders; then they can make tender collusion: agreement to raise the price of proposal to maximize the bidders' profit. This collusion can unidermine the interest of the government and the interest of the entire citizen as taxpayers. Hence, in order to protect those interests, noone should be allowed use transparency as an argument to seek the information of the bidding proposal in that specific time.

To sum up, the elaboration above showed that the concept of transparency has been developed since 17 centuries. The concept then absorbed as principle of good governance. When later on this principle absorbed as principle in public procurement, indeed, it obtained some enhancement. The enhancement was sharpening and detailling about how transparency should be meant in public procurement. The elaboration above has also addressed that principle of transparency should not be implemented in particular time in order to reach the procurement objective.

\section{Principle of Accountability in Good Governance}

In several literatures, it is believed that the concept of accountability is the latest concept which developed under "umbrella concept" of good governance. One may say that the history of accountability starts from the bookkeeping in accountancy. However, this paper believes that the history this concept has been early developed more in the political area rather than in economy area.

Harlow regarded that the term accountability stem in the political accountability as she regarded that the implementation of check and balances in 19 century happened in the UK (Harlow, 2002). It was conducted by the ministers of the Crown had to act responsibility in Parliament. However, even though this paper agree with Harlow that the development of accountability stemmed more in the development of politics, this paper disagree with her about two things on the rest of her arguments.

First, in the European context, the first development concept of accouniability should not be seen from the UK, but from France. Huntington noted that Louis XIII in 1630 refused favor request from her queen mother and her family. He did so by saying: "I am more obligated to the state" (Huntington, 2006). It was not clear about what was precisely favor that was asked by the families; however, it indicated that the request was not rational in the eye of Louis as the policy makers. He then showed his consideration by prioritizing the state interest rather than the favor of royal family. This paper regards that the information above reflects that the "seed" development of accountability in Europe can be traced in 16 century (and not in 19 century), and it started in France and not in the UK.

Second, another reason why this paper challenged Harlow opinion is that she only regarded the development of accountability in western societies. Indeed, this paper found that the concept of accountability has been developed in eastern societies. This development, indeed, had happened in earlier era and in more sophisticated structure than what happened in the weșt.

According to the history of the Buigis Kingdom in 16 century (currently known as South Sulawesi, Indonesia), the concept of accountability existed and implemented in the patronclient political system (Yani, 2007). The clients (joa') promises to serve the king/patron (ajjoareng). The ajjoareng which was usually -but not always- from the royal family member, 
could be impeached by the joa' if he failed in protecting the safety and bringing the prosperity of joa'. According to History, there were two ajjoareng impeached by the joa': La Ica Matinroé ri Addénénna and La Ulio Botéqé Matinroé ri Iterrung (Pelras, 1981).

It is believed that the joa' did not care whether the tax that has paid written correctly by ajjoareng's staff or not; joa' were care more about the output result: prosperity. At that point, it should be meant that the first development of accountability was more on political aspect and not in bookkeeping-accountancy aspect.

The development of the concept above, later on were sharpened as principle of accountability. One that can explain it is Mark Bovens. His idea can be seen as "principle" since the idea has been embodied with how legal system works and implements accountability. The elaboration that mentioned in this sub chapter will be used as analysis tools for examining principle of accountability in public procurement.

Beforehand, Bovens regards that there are seven constitutive elements in order to qualify the work of accountability. The elements are as follows (Bovens, 2006): (i) there should be a relationship between an actor and a forum; (ii) (in which) the actor is obliged; (iii) to explain and justify; (iv) his conduct; ( $v$ ) then, the forum can pose questions; (vi) and pass the judgement; (vii) the actor may face the consequences.

Later on, he extracted the concept above and highlighted three essential components in order to be called accountability relationship (Bovens, Schilleman and t' Hart, 2008): (i) the actor should be obliged to inform the forum about his conduct; (ii) there should be an opportunity for the forum to debate the actor's conduct and the opportunity for the actor to explain and justify the conduct; (iii) the forum and some third parties should be able to pass judgement and consequences to the actor.

Somehow, the essence above has coherences with World Bank point of view that said accountability is a matter of answerability and enforcement (Stapenhurst and O'Brien, last visited 10/10/2012). However, it should be bore in mind that answerability only happen when principle of transparency involved. Hence, this paper regards that the essence of accountability is the principle of transparency, and the availability of the regulation which mandates the actor: to answer the forum's questions, and to obtain sanction from the forum's judgement.

As this paper is about government procurement, then it is important to elaborate the nature of the forum for the government officials (as actor). Again, this paper will owe Bovens' idea which regards there are five forums for the government (Bovens, 2006): First, political accountability which is represented by elected representatives, political parties, voters and media; second, legal accountability which is represented by courts; third, administrative accountability which is manifested by auditors, inspectors and controllers; fourth, professional accountability which is represented by the point of view of professional bodies; fifth, social accountability which manifested by NGOs or interest groups.

This paper agrees with the idea above, and thus that conceptual framework will be used to examine the works of accountability as a principle in public procurement. However, there is one small thing that should be clarified; this paper regards that political accountability mentioned above should be limited only to the political bodies; voters and media should be considered as member in social accountability-forum.

As it has been highlighted, principle of accountability can be existed if three components are available: (principle of) transparency; the availability of the regulation which mandates the actor to answer the forum's questions; and the availability of the regulation which allow the forum to impose sanction to the actor. As transparency has been discussed on the previous part, then the elaboration will be focused on the two last components. 
Those two components, in the public procurement system, should be referred to the possibility to challenge and/or to examine (and then pass the judgement to) the procurement committee's decision in awarding contract. Forums need to know why the committee awards the contract to the winner, and why not to other bidders, or why the committee decides to include or exclude particular tenderers (Trepte, 2007).

This challenge can be based on various elements, such as: (i) examining whether the procurement procedures have been fully conducted by the committee (procedural reasons); (ii) whether the objectives of the procurement have been achieved (substantial reasons); or (iii) combination of those two components.

This paper views that principle of accountability in good governance context is coherence with principle of accountability in procurement context. However, the principle of accountability in procurement system is not situated merely in public procurement law, but also in other laws as anti corruption law, state financial audit law, inspectorate law, etc.. It can be so since the decision of committee ("the actor") can be examined by several "forums".

In Indonesia, the works of the forum are as follows. Parliement members conduct political accountability. They may use their authority to ask particular case/problem in public procurement that becomes the public concerns. An instance for this process can be seen in the efforts of interpellation rights in national sports centre case (http://news.liputan6.com, 21/11/2012). Courts conduct legal accountability. It can be seen in various courts decisions that has released. An instance of these is Supreme Court Decision No $205 \mathrm{~K} / \mathrm{Pid} / 2007$ about corruption ballot seal case in general election commission (KPU) in 2004.

Administrative accountability can be conducted in two main ways. First, the superior of the tender committee can carry it out. The regulation mentioned that someone may challange the winning award decision by submitting appeal to the committee (Art 60 (1) (i), President Regulation No 54/2010). In the next step, if she does not satisfy, she may re-appeal it to the minister and/or the head of the institution (Ibid). Second, inspectorates, government internal auditors, or state financial auditors can also examine the committee decision. One good instance of this is that the state financial auditors release their judgement that there is a various infringements in procurement procedure for electronic ID profects (www.bpk.go.id, last visited 24/10/2012). Profesional accountability happens when intellectual who knows procurement system address his view and make judgement in particular procurment cases. A good example of social accountability can be seen when citizen, media and NGOs criticize togetherly tender corruption in police's simulator driving license (www2.tempo.co, last visited, 21/11/2012).

Indeed, each "forum" above has capacity to impose the sanction. However, the sanction can have two main formulas: legal sanction or moral sanction. Legal sanction can be differentiated into three categories, administrative sanction (in administrative accountability), criminal sanction (in legal accountability), or combination of these two sanctions. The rest forums can only impose moral sanction.

To conclude, elaboration in this chapter firstly has described the concept development of accountability. It has firstly found as political accountability in Bugis Kingdom since 16 century. The similar practice can also be seen in France and the UK in 18-19 century. This concept then embodied as fundamental principle of good governance. This principle can be implemented optimally in public procurement context, even though the fact that the regulations that support this principle is not exclusively in procurement regulation. 


\section{CONCLUSION}

This paper has illustrated the development of the good governance concept which can be traced back long before the era when international organizations firstly distinguished this term. In addition to that, some elements of good governance as equity, transparency, and accountability have been developed since 16 century. The development did not only happen in European kingdom, but also in Bugis Kingdom, which later on become province in Indonesia. Hence, it can be said that principle of good governance is avant la lettre, concept that had been living long time before the particular terminology was coined.

Answering to the main research question, this paper has shown that the concept of good governance has been embodied as the principle of public procurement with some adjustment. It can be so since concept is usually broader, more abstract and more general than principle; thus, in order to be institutionalized in the narrower place like principle, the substance of the concept should be adjusted.

Answering to the three-sub research questions, the elaboration is as follows. The concept of equity in good governance is referred to principle of equality in public procurement. This principle of equality is divided to two components: equality on participation and equality on treatment. These two sub principles are generally implemented; however, in particular condition it can be put aside as to give positive affirmation in the purpose equity reason. The concept of transparency in good governance has been developed as principle of public procurement. This absorption was held by particular adjustment in order to assure that the transparency principle can be implemented optimally in public procurement context. However, in particular time, principle of transparancy should not worked out in order to reach the procurement objective. Almost similar to two concepts above, the concept of accountability has been absorbed as principle of good governance. This principle can directly suit to public procurement system. It can be so as the coherence of this principle with the regulation that directly or indirectly related to procurement regulation.

\section{Bibliography}

Addink, G.H. (2012). Good Governance: Concept and Contex., Utrecht

Arrowsmith, S (ed) (2010). Public Procurement Regulation: An Introduction, in: http://www.nottingham .ac.uk/pprg/documentsarchive/asialinkmaterials/ publicprocurementregulationintroduction.pdf. last checked: 29/12/2012

Bernard, C. (1998). "The Principle of Equality in the Community Context: P. Grant, Kalanske and Marschall, Four Uneasy Bedfellows?", Cambridge Law Journal, Volume 57 (issue 02), pg 363.

Birkinshaw, P. (2006). "Transparency as a Human Rights", Proceeding in British Academy 2006

Botchway, F. (2000-2001). "Good Governance: The Old, The New, The Principle, and The Elements", Florida Journal of International Law, Vol 13, pg 159-210.

Bovens, M. "Analysing and Accessing Public Accountability: A Conceptual Framework", http://igitur-archive.library.uu.nl/USBO/2012-0315-200635/Analysing\%20and\%20 Assessing\%20Public\%20Accountability1.pdf, pg 9. Last visited 12/10/2012

Bovens, M., Schilleman, T., and t'Hart, P. "Does Public Accountability Work?, An Assessment Tools",http://igitur-archive.library.uu.n|/USBO/2009-0818-200207/Does\%20public\%20 accountability\%20work.pdf, pg 234. Last visited: 12/10/2012 
Embodiment Concept of Good Governance (Richo Andi Wibowo)

BPK, Pers Release: "Summary Result of State Financial Audit in the first semester 2012" (Siaran Pers: Hasil Pemeriksaan BPK Semester II 2012) in: http://www.bpk.go.idl web/files/2012/10/SP-IHPS-I-Tahun-2012-edit-2809-BA-presiden.pdf, last accessed 24/10/2012,

Busuoic, M. (2010). The Accountability of European Agencies. Delft: Eburon

French Diplomatir, "The Symbols of Republic", in http://www.diplomatie.gouv.fr/en/francel institutions-and-politics/the-symbols-of-the-republic/article/the-declaration-of-the-rightsof, last visited: $16 / 11 / 2012$

Gisselquist, R.M. "What Does Good Governance Means?", in: http://unu.edu/publications/ articles/what-does-good-governance-mean.html, 19/11/2012

Hardjowiyono, B and Muhammad, H. (2006). Toolkit Anti Korupsi Bidang Pengadaan Barang dan Jasa Pemerintah. Jakarta: Kormonev Kementerian Pendayagunaan Aparatur Negara.

Harlow, C. (2002). Accountability in the European Union. Oxford: Oxford University Press.

Huntington, S. (2006). Political Order in Changing Societies. New Haven: Yale University Press.

loain Brumer, "A Brief History of Procurement: Golden Ages Past and To Come", in: http://www. procurement-iu.com/blog/2012/2/a brief_history_of_procurement_golden_ages_past and to come, last visited $28 / 10 / 2012$

IFAD, "Good Governance: an Overview", in http://www.ifad.org/gbdocs/eb/67/e/EB-99-67INF-4.pdf, last accessed: 20/11/2012

International Covenant on Civil and Political Rights, in: http://www2.ohchr.org/english/law/ccpr. htm\#art19, last visited 28/12/2012

IMF, 'The IMF and Good Governance', in: http://www.imf.org/external/np/exr/facts/gov.htm, last accessed: 20/11/2012

Kostyo, $\mathrm{H}$ (ed). (2006). Handbook for Curbing Corruption in Public Procurment, Transperency International, Berlin.

Kranich, M. "Equality and Equity of Access: What's the Difference", see: http://www.ala.org/ offices/oif/iftoolkits/toolkitrelatedlinks/equalityequity, last accessed 16/11/2012.

Legal Dictionary, in: http://legal-dictionary.thefreedictionary.com/Equality+is requity, last accessed: $14 / 11 / 2012$

Liputan 6, "Lihat Secara Jernih Interpelasi Hambalang", in: http://news.liputan6.com/ read/455593/anas-lihat-secara-jernih-interpelasi-hambalang. last visited: 21/11/2012

Melten, J.v.H. (2004). The Rise of Public in Enlightenment Europe. Cambridge: Cambridge University Press.

Maldonando, N. (2010). "The World Bank's Evolving Concept of Good Governance and its Impact on Human Rights", Stockholm.

NN, Biography, 'Louis XVl', in: http://www.biography.com/people/louis-xvi-9386943?page=2, last visited: $20 / 11 / 2012$ 
UNISIA, Vol. XXXIV No. 76 Januari 2012

OECD, Integrity in Public Procurement, Good practice from A to Z, 2007, in http://www.oecd. org/dataoecd/43/36/38588964.pdf, last accessed 16/06/2011.

Pelras, C (no information about year; however, beforehand the paper was presented in 1981), "Patron Clients Ties Among the Bugis and Makasarese of South Sulawesi", see: http:/l www.sabrizain.org/malava/library/patronclient.pdf, last accessed 20/11/2012

Thai, K.V. (2001). "Public Procurement: Re-Examined", Journal of Public Procurement, Vol 1, 2001

Trapte, P. (2007). Public Procurement in the EU. New York.

President Regulation (of Republic Indonesia) No 54/2010 about Procurement in Goods/ Services

Stapenhurst, R. and O'Brien, M. http://siteresources.worldbank.org/ PUBLICSECTORANDGOVERNANCE/Resources/AccountabilityGovernance.pdf, last visited $10 / 10 / 2012$

Karsam, R. "Equality Vs Equity", in http://webcache.gooqleusercontent.com/search?q=cache: w4jpiA3qTWcJ:events.kenexa.com/newsletter/oldver/09051.asp\%3Fuid\%3D1\%26tbl\%3 Dtest $+\& c d=2 \& h l=e n \& c t=c i n k, 16 / 11 / 2012$

Tempo, "Hundreds people participate in demonstration about \#save KPK", in http://www2. tempo.co/read/news/2012/10/07/078434195/Ratusan-Orang-Ikuti-Aksi-Save-KPK-di-HI, $21 / 11 / 2012$.

The US Declaration of Independance, in: http://www.archives.qov/exhibits/charters/declaration transcript.html, 16/11/2012

Transparency International, "FAQs on Corruption", in: http://www.transparency.org/whoweare/ organisation/fags on_corruption\#transparency, 09/10/2012

UNCITRAL Model Law on Procurement (Official Records of the General Assembly, Sixty-sixth Session, Supplement No. 17 (A/66/17), annex I), in: http://www.uncitral.org/pdf/english/ texts/procurem/ml-procurement-2011/ML_Public Procurement_A_66_17_E.pdf, last visited $21 / 11 / 2012$

UNDP, "Good Governance and Sustainable Human Development", in: http://mirror.undp.org/ magnet/Docs/dec/DECEN923/Casestud.htm, 20/11/2012

UNDPPC. "Freedom of Information", in: http://www.undppc.org.fi/pages.cfm/our-work/ democratic-governance/accountability-transparency-frameworks/freedom-ofinformation/, 20/11/2012.

Universal Declaration of Human Rights, in: http://www.un.org/en/documents/udhr/index. $\underline{\text { shtmil\#a19, }}$

Weber, M. (1978). Economy and Society. University of California Press.

Yani, A.A. (2007). "Budaya Politik Orang Bugis Dalam Dinamika Politik Lokal" (Bugisnese Political Culture in Local Politics), Jurnal Masyarakat dan Budaya, Lembaga limu Pengetahuan Indonesia (LIPI), Volume 9, No.2, p. 7. 